\title{
Chemical sterilization in in vitro propagation of Arundina bambusifolia Lindl. and Epidendrum ibaguense Kunth
}

\author{
Donizetti Tomaz Rodrigues ${ }^{1}$, Roberto Ferreira Novais ${ }^{2}$, Víctor Hugo Alvarez Venegas ${ }^{2}$, José Maria Moreira Dias ${ }^{3}$, \\ Wagner Campos Otoni ${ }^{4}$ Ecila Mercês de Albuquerque Villani ${ }^{5}$
}

\begin{abstract}
There is a great demand for simpler and less costly laboratory techniques and for more accessible procedures for orchid breeders who do not have the necessary theoretical basis to use the traditional seed and clone production methods of orchids in vitro. The aim of this study was to assess the use of sodium hypochlorite $(\mathrm{NaClO})$ as a decontaminant in the process of inoculating adult orchid explants of Arundina bambusifolia and Epidendrum ibaguenses. Solutions of $\mathrm{NaClO}\left(1.200,2.400,3.600,4.800\right.$ and $6.000 \mathrm{mg} \mathrm{L}^{-1}$ - equivalent to 50, 100, 150, 200 and $250 \mathrm{~mL} \mathrm{~L}^{-1}$ of commercial bleach - CB) were sprayed on the explants (1.0 mL) and the culture medium (GB5), in the presence or absence of activated charcoal $\left(2 \mathrm{~g} \mathrm{~L}^{-1}\right)$. The explants used were nodal segments of field-grown adult plants. The procedures for inoculating the explants were conducted outside the laminar flow chamber (LFC), except for the control treatment (autoclaved medium and explant inoculation inside the LFC). The best results for fresh weight yield, height and number of shoots were obtained using $\mathrm{NaClO}$ in solution at $1.200 \mathrm{mg} \mathrm{L}^{-1}$ (equivalent to $50 \mathrm{~mL} \mathrm{~L}^{-1} \mathrm{commercial}$ bleach) with activated charcoal in the culture medium. Fresh weight figures were $1.10 \mathrm{~g} / \mathrm{jar}$ for Arundina bambusifolia and $0.16 \mathrm{~g} / \mathrm{jar}$ for Epidendrum ibaguenses. Spraying the $\mathrm{NaClO}$ solutions controls the contamination of the culture medium already inoculated with the explants. .
\end{abstract}

Key words: tissue culture, contamination, sodium hyplochlorite, orchid.

\section{RESUMO}

\section{Esterilização química na propagação in vitro de Arundina bambusifolia Lindl. e Epidendrum ibaguense Kunth}

Há uma grande demanda por técnicas de laboratório mais simples, e de menor custo, e por procedimentos mais acessíveis, por parte de orquidófilos que não têm o embasamento teórico necessário à utilização de métodos usuais de produção, seminífera e clonal, de orquídeas, in vitro. O objetivo deste trabalho foi avaliar a eficiência da aplicação de hipoclorito de sódio $(\mathrm{NaClO})$, para a descontaminação, no processo de inoculação de explantes de orquídeas das espécies Arundina bambusifolia e Epidendrum ibaguenses. As soluções de $\mathrm{NaClO}(1.200 ; 2.400 ; 3.600 ; 4.800$ e 6.000 $\mathrm{mg} \mathrm{L}^{-1}$ - equivalentes a 50; 100; 150; 200 e $250 \mathrm{~mL} \mathrm{~L}^{-1}$ de água sanitária comercial - ASC) foram borrifadas (1,0 mL) sobre explantes e meio de cultura (GB5), na ausência ou na presença de carvão ativado $\left(2 \mathrm{~g} \mathrm{~L}^{-1}\right)$. Os explantes utilizados foram segmentos nodais de plantas adultas, cultivadas a campo. Os procedimentos para inoculação dos explantes foram

Received: 18/08/2011; Accepted: 27/03/2013

${ }_{1}^{1}$ Agronomist Engineer, Doctor of Science. Departamento de Solos, Universidade Federal de Viçosa, Campus Viçosa, Avenida Peter Henry Rolfs, s/n, 36570-000, Viçosa, Minas Gerais, Brazil. donitom@yahoo.com.br

${ }^{2}$ Agronomist Engineer, Ph.D. Departamento de Solos, Universidade Federal de Viçosa, Campus Viçosa, Avenida Peter Henry Rolfs, s/n, 36570-000, Viçosa, Minas Gerais, Brazil. rfnovais@ufv.br,vhav@ufv.br

${ }^{3}$ Agronomist Engineer, Doctor of Science. Departamento de Fitotecnia, Universidade Federal de Viçosa, Campus Viçosa, Avenida Peter Henry Rolfs, s/n. 36570-000, Viçosa, Minas Gerais, Brazil.jmmdias@ufv.br

${ }^{4}$ Agronomist Engineer, Ph.D. Departamento de Biologia Vegetal, Universidade Federal de Viçosa, Campus Viçosa, Avenida Peter Henry Rolfs, s/n, 36570-000, Viçosa, Minas Gerais, Brazil. wotoni@ufv.br

${ }^{5}$ Agronomist Engineer, Doctor of Science. Departamento de Solos, Universidade Federal de Viçosa, Campus Viçosa, Avenida Peter Henry Rolfs, s/n, 36570-000, Viçosa, Minas Gerais, Brazil. ecilavillani@hotmail.com (corresponding author). FAPEMIG scholarship. 
realizados fora da câmara de fluxo laminar (CFL), exceto no tratamento controle (meio autoclavado e inoculação dos explantes em condições de CFL). Máxima produção de matéria fresca, altura e número de brotações foi obtida com 1.200 $\mathrm{mg} \mathrm{L}^{-1}$ de $\mathrm{NaClO}$ (equivalente a $50 \mathrm{~mL} \mathrm{~L}^{-1}$ de ASC), na presença de carvão ativado no meio de cultura, correspondente à matéria fresca de 1,10 e $0,16 \mathrm{~g} /$ frasco, para Arundina bambusifolia e Epidendrum ibaguenses, respectivamente. A pulverização de soluções de $\mathrm{NaClO}$ controla a contaminação de meio de cultura já inoculado com o explante.

Palavras-chave: cultura de tecido, contaminação, hipoclorito de sódio, orquídea.

\section{INTRODUCTION}

The production of orchid seedlings using tissue cultures has attracted increasing interest from orchidgrowers for multiplying the best genotypes of the progenies of various crosses and, in particular, for increasing the availability of native plant species and varieties, some of which are under threat of extinction, making them more accessible at lower cost (Stacanto et al., 2001).

A number of studies have been conducted to find a way of making decontamination methods feasible for amateur growers and non-specialized people, some of them centered on assessing the need to use autoclaves and laminar flow chambers (LFC). Studies involving the use of sodium hypochlorite $(\mathrm{NaClO})$ have clearly shown how it can be used as diluted solution, often promoting better growth of in vitro tissues, as verified in the germination of rice (Chun et al., 1997), orchid seeds (Alvarez-Pardo et al., 2006; Rodrigues et al., 2011), and the cloning of Eucalyptus (Teixeira et al., 2008).

Teixeira et al. (2006) used weak solutions of $\mathrm{NaClO}(1$, 3, 5, 7 and $9 \mathrm{mg} \mathrm{L}^{-1}$ ) added to culture media to control contamination in banana. In the autoclaved control, 25\% of jars were contaminated, compared with only $10 \%$ using a medium containing $1 \mathrm{mg} \mathrm{L}^{-1} \mathrm{NaClO}$. At higher concentrations, there was no contamination and the tissues were unharmed. Sterilizing the culture medium using $\mathrm{NaClO}$ doubled the fresh weight yield $(76 \mathrm{mg} / \mathrm{jar}$ ) in comparison to the autoclaved medium ( $32 \mathrm{mg} / \mathrm{jar}$ ), and results were similar regardless of the concentration of $\mathrm{NaClO}$.

Sodium hypochlorite and calcium hypochlorite $\mathrm{Ca}(\mathrm{ClO})_{2}$ - are commonly used as sterilizing agents for explants grown in vitro. In experiments on apples, contamination control was improved using $\mathrm{NaClO}$, but explant oxidation was higher by comparison with the use of $\mathrm{Ca}(\mathrm{ClO})_{2}$ (Erig \& Schuch., 2003).

Spraying seeds of Bletilla striata, Cattleya loddigessi, Dendrobium kingianum, Habenaria radiata and Phalaenopsis spp. with $\mathrm{NaClO}$ or $\mathrm{H}_{2} \mathrm{O}_{2}$ sterilizing solutions at different concentrations, Yanagawa et al. (1995) found $100 \%$ germination, even at high hypochlorite concentrations $\left(5,000 \mathrm{mg} \mathrm{L}^{-1}\right.$ active $\left.\mathrm{Cl}\right)$, and seed mortality and medium contamination dropped to zero. They also obtained similar results in transplanted explants using the solutions in spray form, without impairment of seedling growth. The responses to $\mathrm{H}_{2} \mathrm{O}_{2}$ were similar when used at concentrations of $0.1 \mathrm{~g} \mathrm{~L}^{-1}(0.01 \%)$, both added to the culture medium and using spray application.

The use of activated charcoal in the culture medium, a form of carbon with a high surface area, is known to present elevated capacity to adsorb numerous toxic compounds during in vitro cultivation (Nunes et al., 2008), such as phenolic exudates and excess ethylene produced inside the culture jars (Ribeiro et al., 2000; Chagas et al., 2005; Thomas, 2008).

The aim of this study was to assess the response of inoculated explants in non-sterile culture media (no prior autoclaving) using solutions of $\mathrm{NaClO}$ at various concentrations, sprayed on the explants in the culture medium, in the absence or presence of activated charcoal.

\section{MATERIALS AND METHODS}

The experiments were conducted in the Plant Cell and Tissue Laboratory of the Departamento de Biologia Vegetal at Universidade Federal de Viçosa, in the state of Minas Gerais (MG), Brazil. The culture medium consisted of Gamborg 5 salts - GB5 (Gamborg et al., 1968), $20 \mathrm{~g} \mathrm{~L}^{-1}$ sucrose, $6 \mathrm{~g} \mathrm{~L}^{-1}$ agar and $100 \mathrm{~mL} \mathrm{~L}^{-1}$ of green coconut water, adjusting the $\mathrm{pH}$ to 5.5 in the control treatment, each culture jar contained $25 \mathrm{~mL}$ of the medium autoclaved at $121^{\circ} \mathrm{C}$ for $20 \mathrm{~min}$.

All procedures of the sodium hypochlorite treatments were carried out outside the laminar flow chamber (LFC). Each treatment consisted of applying $1 \mathrm{~mL}$ of the respective sterilization solution in spray form over the solid (cooled) culture medium and explants. The control treatment consisted of using the conventional micropropagation method, conducting all procedures inside the LFC and not applying $\mathrm{NaClO}$.

The experiment was arranged in a randomized block factorial design of $(2 \times 5)+1$ : absence or presence of activated charcoal $\left(2.0 \mathrm{~g} \mathrm{~L}^{-1}\right)$, five concentrations of sodium hypochlorite $(1.200,2.400,3.600,4.800$ and 6.000 
$\mathrm{mg} \mathrm{L}^{-1}$ ) in the form of commercial bleach (CB), at concentrations corresponding to 50,100, 150, 200 and 250 $\mathrm{mL} \mathrm{L}^{-1}$, plus a control treatment with five replications.

The plant material consisted of Arundina bambusifolia nodal segments obtained from a home-grown clump in the municipality of Ouro Preto, Minas Gerais state, and nodal segments of aerial shoots of Epidendrium ibaguenses, grown in the ornamental plants section at Departamento de Fitotecnia, Universidade Federal de Viçosa. The plant ma-
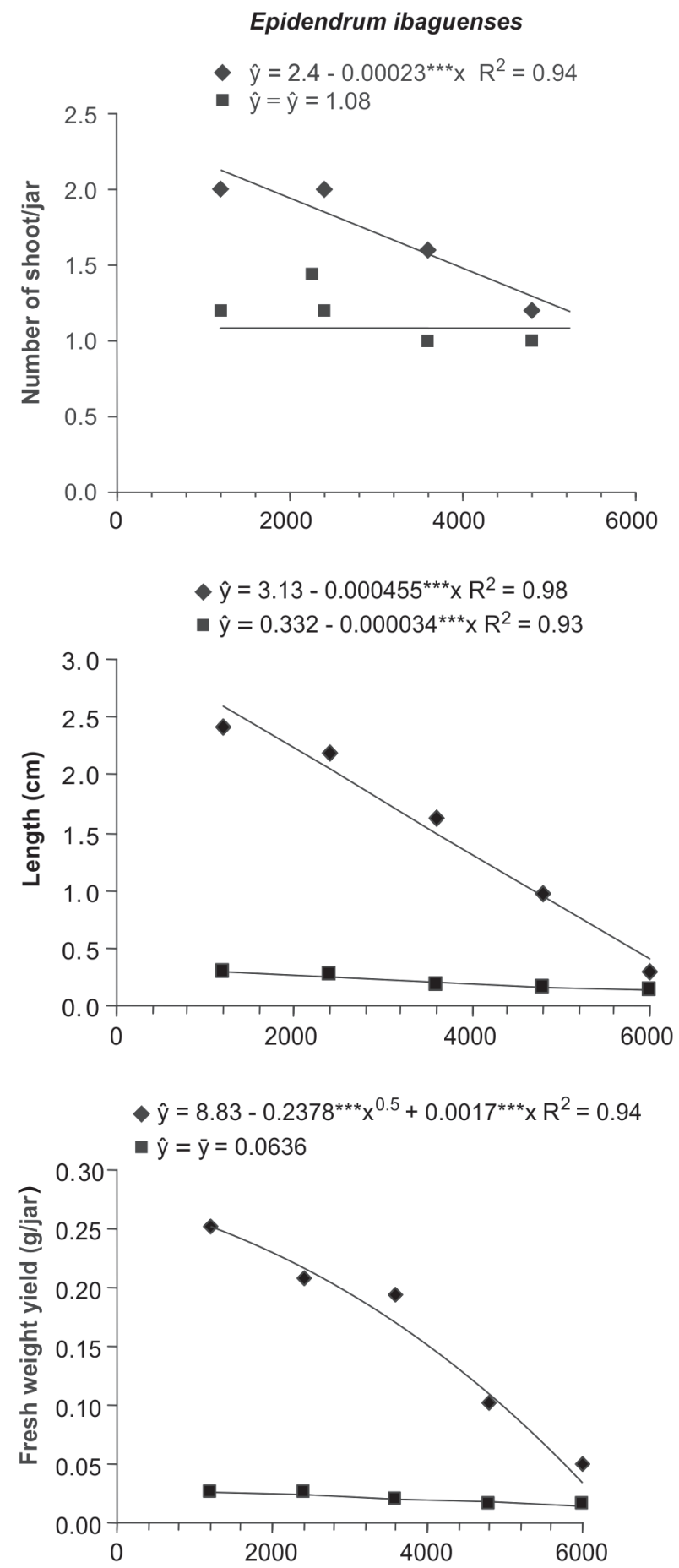

terial was washed with neutral detergent in running water, then surface sterilized in $70 \%$ alcohol for $1 \mathrm{~min}$, and after discarding the alcohol, in commercial bleach $\left(24 \mathrm{~mL} \mathrm{~L}^{-1}\right)$ for $15 \mathrm{~min}$, and rinsed with autoclaved water.

The experimental unit was a $234 \mathrm{~mL}$ jar containing 25 mL of GB5 medium (Gamborg et al., 1968) inoculated with three nodal segments of Arundina bambusifolia Lindl. or Epidendrum ibaguenses Kunth. The culture jars were sealed with PVC-lined polypropylene plugs.

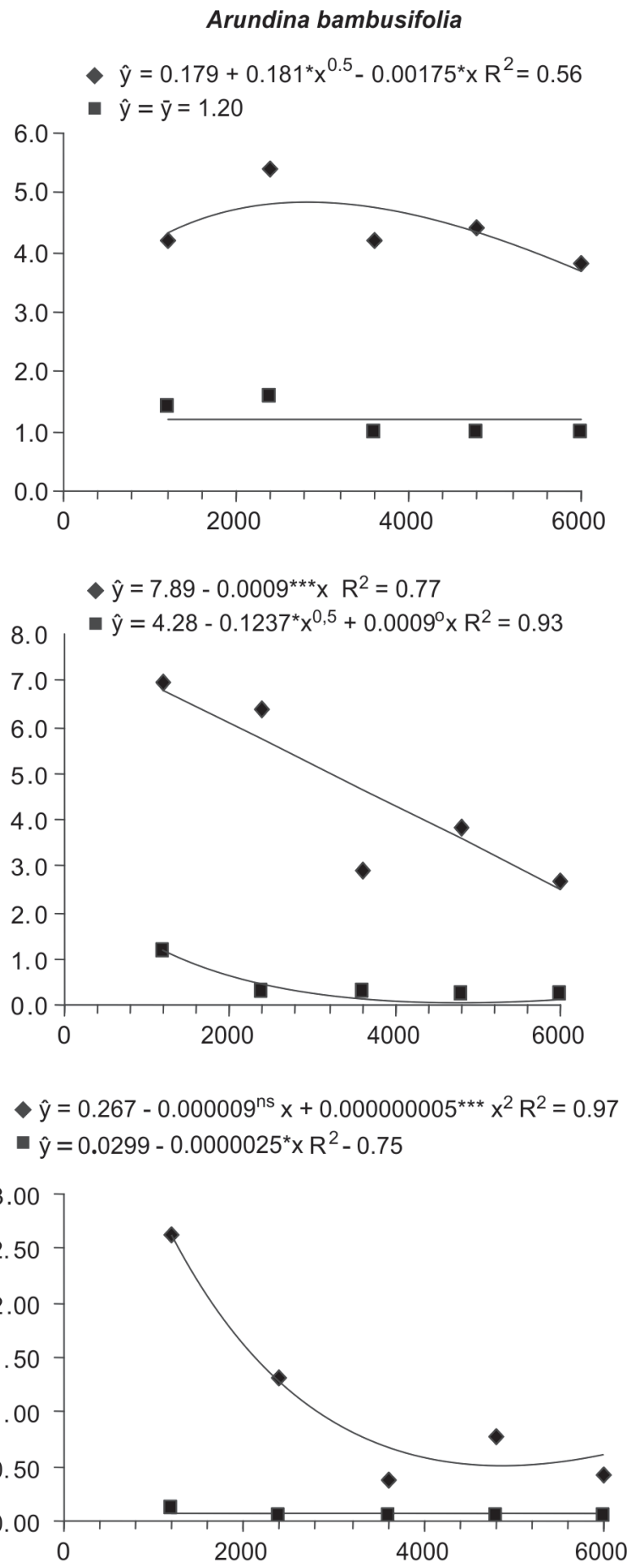

Figure 1. Responses of Epidendrum ibaguenses and Arundina bambusifolia to sprayed solutions of sodium hypochlorite, in the absence ( $\boldsymbol{\square})$ or presence $(\bullet)$ of activated charcoal. 
The same procedures were used for the control treatment, except that after sterilization in alcohol, the explants were handled inside the LFC. For this trial, all jars containing medium were autoclaved at $121^{\circ} \mathrm{C}$ for $20 \mathrm{~min}$. No chemical agents were added to sterilize the medium at this stage.

After treating with $\mathrm{NaClO}$ and inoculating the explants, the jars were kept in a culture room at $27 \pm 2{ }^{\circ} \mathrm{C}$, with a $16 /$ $8 \mathrm{~h}$ (light/dark) photoperiod and irradiance of $48 \mu \mathrm{mol} \mathrm{m}^{-2}$ $\mathrm{s}^{-1}$. The experiment was assessed in terms of explant oxidation, contamination by bacteria and/or fungi, and fresh weight yield, height and number of shoots.

The results were subjected to analysis of variance and the regression equations of the variables studied were adjusted according to the treatments $(\mathrm{NaClO}$ with or without activated charcoal), using the SAEG 9.0 software.

\section{RESULTS AND DISCUSSION}

The growth and development variables evaluated for Arundina bambusifolia and Epidendrum ibaguenses indicated that the best results were obtained in the presence of activated charcoal (AC). The results of number of side shoots, length and fresh weigh yield for $A$. bambusifolia and E. ibaguenses, are presented on Figure 1. Figure 2 shows the response of Arundina bambusifolia to sprayed solutions of sodium hypochlorite $(\mathrm{NaClO})$ in the absence or presence of activated charcoal. These results are in agreement with those obtained by Kent et al. (2004), who reported the positive effects of adding 0.5 $\mathrm{g} \mathrm{L}^{-1} \mathrm{AC}$ on fresh weight yield and shoot length for nodal explants of Anoectochilus formosamus.

For Catasetum fimbriatum, the addition of $0.5 \mathrm{~g} \mathrm{~L}^{-1}$ of $\mathrm{AC}$ to the Knudson $\mathrm{C}$ medium led to an increase in the number of leaves per explant, in comparison with cultures containing no AC (Morales et al., 2006). In the presence of $0.2 \mathrm{~g} \mathrm{~L}^{-1} \mathrm{AC}$, green somatic embryos of Rhynchostylis rubrum exhibited strong development from embryogenic calluses in NDM and VW media; embryo development was $80 \%$ in the NDM medium and $19 \%$ in the VW medium (Te-chato et al., 2010).

Increasing the concentration of $\mathrm{NaClO}$ in the spray solution decreased the fresh weight yield, the number of shoots and shoot length for both species (Figure 1).

There was a decrease in medium contamination in jars treated with $\mathrm{NaClO}$. However, in the control, we found an average of five bacterial colonies per jar for both species, as well as fungi, but only in the jars containing $A$. bambusifolia. Contamination was higher in the presence of AC, possibly due to adsorption of some chlorine, reducing the effect of the $\mathrm{NaClO}$ on microorganisms in the explant. In contrast, Ket et al. (2004) mentioned that the presence of $\mathrm{AC}$ in the culture medium reduced the effect of phenols released by in vitro cultured plant tissues, which in some cases can kill the explant in only a few hours.

Similar results were obtained for fungus contamination in the control (LFC) and in treatments with $\mathrm{NaClO}$, whereas bacterial contamination was generalized for both species in the control (using the laminar flow chamber and without addition of $\mathrm{NaClO}$ to the jar), impairing tissue growth and development (Table 1).

Studies on $\mathrm{NaClO}$ have shown that the application of diluted solution often promotes superior growth of in vitro tissues of different plant species (Chun et al., 1997; Ervin \& Wetzel, 2002; Teixeira et al., 2008). However, in our study, increased doses of $\mathrm{NaClO}$ had a harmful effect, most likely due to the decontaminant toxicity as the concentration

Table 1. Bacterial and fungal contamination in jars containing tissue of Arundina bambusifolia and Epidendrum ibaguenses, in response to doses of sodium hypochlorite $(\mathrm{NaClO})$, in the absence or presence of activated charcoal in the culture medium. Numbers in parentheses refers to percentage of colonies per jar

\begin{tabular}{|c|c|c|c|c|c|}
\hline \multirow{2}{*}{$\mathrm{NaClO}$} & \multirow{2}{*}{$\begin{array}{l}\text { Activated } \\
\text { charcoal }\end{array}$} & \multicolumn{2}{|c|}{ Arundina bambusifolia } & \multicolumn{2}{|c|}{ Epidendrum ibaguenses } \\
\hline & & Fungal & Bacterial & Fungal & Bacterial \\
\hline$g \mathbf{L}^{-1}$ & $g \mathbf{L}^{-1}$ & \multicolumn{4}{|c|}{ colonies/jars (\%) } \\
\hline $0^{(1)}$ & $2^{(1)}$ & $1(20)$ & $5(100)$ & $0(0)$ & $5(100)$ \\
\hline 1.200 & 0 & $1(20)$ & $0(0)$ & $0(0)$ & $1(20)$ \\
\hline 2.400 & 0 & $0(0)$ & $0(0)$ & $0(0)$ & $1(20)$ \\
\hline 3.600 & 0 & $1(20)$ & $0(0)$ & $0(0)$ & $1(20)$ \\
\hline 4.800 & 0 & $0(0)$ & $1(20)$ & $0(0)$ & $1(20)$ \\
\hline 6.000 & 0 & $0(0)$ & $0(0)$ & $0(0)$ & $0(0)$ \\
\hline 1.200 & 2 & $3(60)$ & $3(60)$ & $2(40)$ & $1(20)$ \\
\hline 2.400 & 2 & $0(0)$ & $3(60)$ & $0(0)$ & $1(20)$ \\
\hline 3.600 & 2 & $0(0)$ & $1(20)$ & $0(0)$ & $0(0)$ \\
\hline 4.800 & 2 & $0(0)$ & $1(20)$ & $0(0)$ & $1(20)$ \\
\hline 6.000 & 2 & $0(0)$ & $1(20)$ & $0(0)$ & $0(0)$ \\
\hline
\end{tabular}

(1) Control treatment.

Rev. Ceres, Viçosa, v. 60, n.4, p. 447-451, jul/ago, 2013 


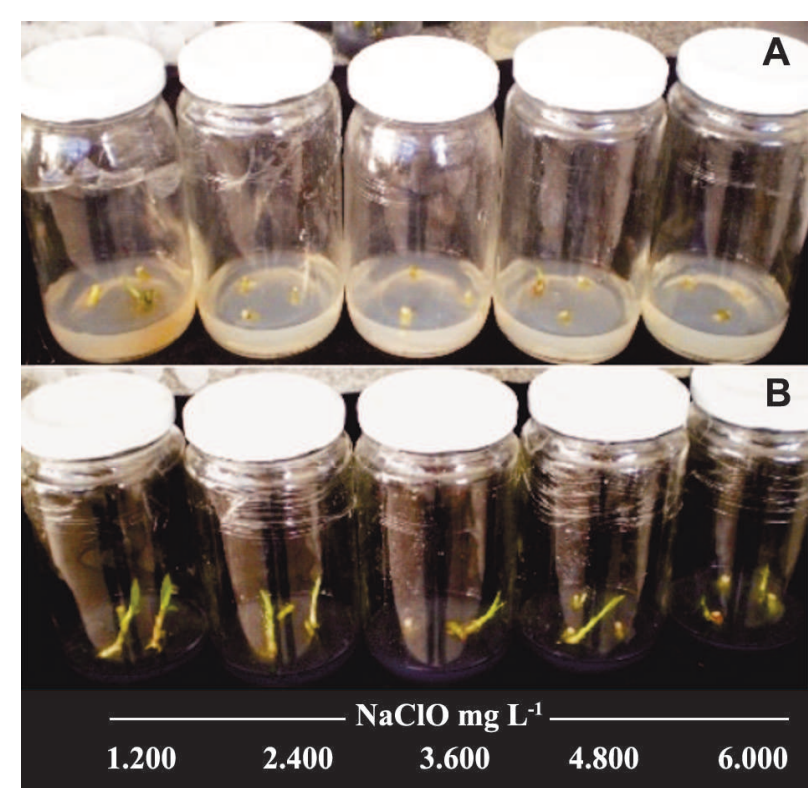

Figure 2. Response of Arundina bambusifolia to sprayed solutions of sodium hypochlorite $(\mathrm{NaClO})$ in the absence $(\mathrm{A})$ or presence (B) of activated charcoal, after 60 days in culture.

increased. On the other hand, the lowest $\mathrm{NaClO}$ concentration was effective in controlling microbial contamination and promoting explant growth (Figure 2), in contrast to the results obtained in the control with the experimental procedure conducted in the LFC and without $\mathrm{NaClO}$ spraying (Table 1).

\section{CONCLUSIONS}

Spraying $\mathrm{NaClO}$ solution over the culture medium after it has been inoculated with the explant (nodal segments) helps control contamination.

Higher concentrations of $\mathrm{NaClO}$ impair plant growth.

In terms of fresh weight yield, number of shoots and shoot length, the best results were obtained in the presence of activated charcoal. However, the charcoal treatment caused increase in bacterial and fungal contamination.

\section{ACKNOWLEDGEMENT}

The authors thank the Fundação de Amparo à Pesquisa do Estado de Minas Gerais (FAPEMIG) for the PosDoctorate scholarship to Ecila Mercês de Albuquerque Villani.

\section{REFERENCES}

Alvarez-Pardo VM, Ferreira AG \& Nunes VF (2006) Seed disinfestation methods for in vitro cultivation of epiphyte orchids from Southern Brazil. Horticultura Brasileira, 24: 217-220.

Chagas EA, Pasqual M, Ramos JD, Pio LAS, Dutra LF \& Cazetta JO (2005) Cultivo de embriões imaturos de citros em diferentes concentrações de carvão ativado e ácido giberélico. Ciência e Agrotecnologia, 29:1125-1131.
Chun SC, Schneider RW \& Cohn MA (1997) Sodium hypochlorite: Effect of solution $\mathrm{pH}$ on rice seed disinfestations and its direct effect on seedling growth. Plant Disease, 81: 821-824.

Erig AC \& Schuch MW (2003) Tipo de explante e controle da contaminação e oxidação no estabelecimento in vitro de plantas de macieira (Malus domestica Borkh.) cvs. Galaxy, Maxigala e Mastergala. Revista Brasileira de Agrociência 9:221-227.

Gamborg OL, Miller RA \& Ojima K (1968) Nutrient requirements of suspension cultures of soybean root cells. Experimental Cell Research, 50:151-158.

Ket NV, Hahn EJ, Park SY, Chakrabarty D \& Paek KY (2004) Micropropagation of an endangered orchid Anoectochilus formosamus. Biologia Plantarum, 48:339-344.

Morales S, Milaneze MAG \& Machado MFPS (2006) Effect of activated charcoal for seedlings development of Catasetum fimbriatum Lindl (Orchidaceae). Journal of Plant Science, 1:388391.

Nunes CF, Pasqual M, Santos DN, Custódio TN \& Araújo AG (2008) Diferentes suplementos no cultivo in vitro de embriões de pinhão-manso. Pesquisa Agropecuária Brasileira, 43:9-14.

Ribeiro VG, Sanábio D, Souza CN, Lopes PSN, Bocardo MR \& Pasqual M (2000) Efeitos de ácido giberélico e carvão ativado no cultivo in vitro de Citrus limonia Osbeck x Poncirus trifoliata (L.) Raf. Pesquisa Agropecuária Brasileira, 35:27-30.

Rodrigues DT, Novais RF, Alvarez V. VH, Dias JMM, Villani EMA \& Otoni WC (2011) In vitro germination of Cattleya intermedia R. Graham by means of chemical disinfection and without laminar flow. Propagation of Ornamental Plants, 11:119-124.

Stancato GC, Bemelmans PF \& Vegro CLR (2001) Produção de mudas de orquídeas a partir de sementes in vitro e sua viabilidade econômica: Estudo de Caso. Revista Brasileira de Horticultura Ornamental, 7:25-33.

Te-chato S, Kongruk S \& Khaimuk W (2010) Micropropagation of Chang Daeng (Rhynchostylis rubrum) by embryogenic callus. Journal of Agricultural Technology, 6:589-597.

Teixeira SL, Ribeiro JM \& Teixeira MT (2006) Influence of $\mathrm{NaClO}$ on nutrient medium sterilization and on pineapple (Ananas comosus cv Smooth cayenne) behavior. Plant Cell, Tissue and Organ Culture, 86:375-378.

Teixeira SL, Ribeiro JM \& Teixeira MT (2008) Utilização de hipoclorito de sódio na esterilização de meio de cultura para multiplicação in vitro de Eucalyptus pellita L. Ciência Florestal, 18:185-191.

Thomas TD (2008) The role of activated charcoal in plant tissue culture. Biotechnology Advances, 26:618-631.

Yanagawa T, Nagai M, Ogino T \& Maeguchi R (1995) Application of disinfectants to orchid seeds, plantlets and media as a mean to prevent in vitro contamination. Lindleyana, 10:33-36. 